Received: 23 November 2015 Accepted: 24 May 2017 Published online: 06 July 2017
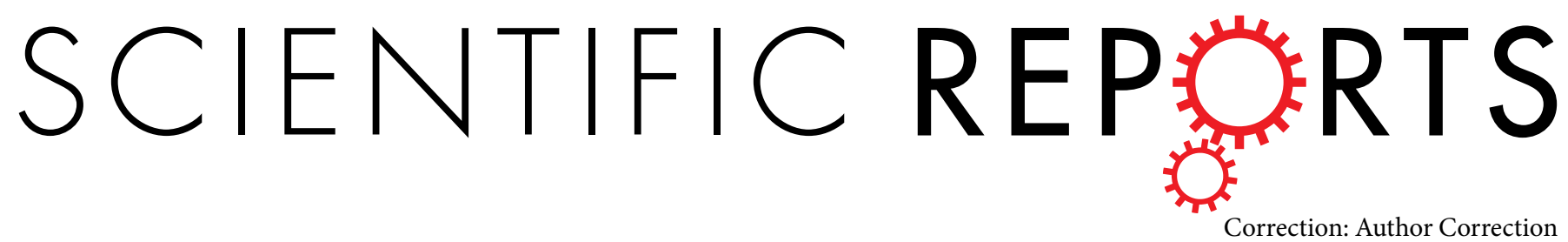

OPEN

\section{Low oxygen eddies in the eastern tropical North Atlantic: Implications for $\mathrm{N}_{2} \mathrm{O}$ cycling}

\author{
D. S. Grundle ${ }^{1,2}$, C. R. Löschere1,3, G. Krahmann ${ }^{1}$, M. A. Altabet ${ }^{4}$, H. W. Bange ${ }^{1}$, J. Karstensen ${ }^{1}{ }^{1}$, \\ A. Körtzinger $\mathbb{D}^{1}$ \& B. Fiedler ${ }^{1}$
}

Nitrous oxide $\left(\mathrm{N}_{2} \mathrm{O}\right)$ is a climate relevant trace gas, and its production in the ocean generally increases under suboxic conditions. The Atlantic Ocean is well ventilated, and unlike the major oxygen minimum zones (OMZ) of the Pacific and Indian Oceans, dissolved oxygen and $\mathrm{N}_{2} \mathrm{O}$ concentrations in the Atlantic $O M Z$ are relatively high and low, respectively. This study, however, demonstrates that recently discovered low oxygen eddies in the eastern tropical North Atlantic (ETNA) can produce $\mathrm{N}_{2} \mathrm{O}$ concentrations much higher (up to $115 \mathrm{nmol} \mathrm{L}^{-1}$ ) than those previously reported for the Atlantic Ocean, and which are within the range of the highest concentrations found in the open-ocean OMZs of the Pacific and Indian Oceans. $\mathrm{N}_{2} \mathrm{O}$ isotope and isotopomer signatures, as well as molecular genetic results, also point towards a major shift in the $\mathrm{N}_{2} \mathrm{O}$ cycling pathway in the core of the low oxygen eddy discussed here, and we report the first evidence for potential $\mathrm{N}_{2} \mathrm{O}$ cycling via the denitrification pathway in the open Atlantic Ocean. Finally, we consider the implications of low oxygen eddies for bulk, upper water column $\mathrm{N}_{2} \mathrm{O}$ at the regional scale, and point out the possible need for a reevaluation of how we view $\mathrm{N}_{2} \mathrm{O}$ cycling in the ETNA.

Nitrous oxide $\left(\mathrm{N}_{2} \mathrm{O}\right)$ is an important climate-relevant trace gas and the oceans are thought to contribute approximately $35 \%$ of all natural sources to the atmosphere ${ }^{1}$. In the troposphere $\mathrm{N}_{2} \mathrm{O}$ acts as a greenhouse gas and has a global warming potential which is $\sim 300$ times that of $\mathrm{CO}_{2}$ over 100 year time-scales ${ }^{2}$. Due to its relative chemical stability, $\mathrm{N}_{2} \mathrm{O}$ also survives transport to the stratosphere where it undergoes photochemical reactions that destroy ozone $e^{3}$. In the oceans, $\mathrm{N}_{2} \mathrm{O}$ is produced via the nitrification and denitrification pathways. During nitrification, $\mathrm{N}_{2} \mathrm{O}$ can be produced as a by-product during ammonia oxidation $(\mathrm{AO})$, or through nitrifier-denitrification whereby AO organisms reduce nitrite $\left(\mathrm{NO}_{2}{ }^{-}\right)$to $\mathrm{N}_{2} \mathrm{O}$. In oxygenated waters, nitrification- $\mathrm{N}_{2} \mathrm{O}$ yields (i.e. those arising from either $\mathrm{AO}$ or nitrifier-denitrification) are small, however, under low $\mathrm{DO}$ concentrations nitrification- $\mathrm{N}_{2} \mathrm{O}$ yields may increase substantially ${ }^{4,5}$. As DO concentrations approach anoxic conditions, denitrification can also be 'turned on', and although it can both produce and consume $\mathrm{N}_{2} \mathrm{O}$, net denitrification yields up to $2 \%$ have been observed ${ }^{6,7}$.

Due to the sensitivity of $\mathrm{N}_{2} \mathrm{O}$ production to low oxygen conditions, the greatest oceanic accumulations, and likely the largest fluxes to the atmosphere, occur in the vicinity of suboxic and anoxic oxygen minimum zones (OMZs), such as those found in the Arabian Sea and the eastern tropical Pacific ${ }^{8-10}$. In comparison, the more ventilated Atlantic Ocean, with higher oxygen concentrations ${ }^{11,12}$, has lower $\mathrm{N}_{2} \mathrm{O}$ production and concentrations ${ }^{13,14}$. Here, we demonstrate for the first time, however, that recently discovered low oxygen mesoscale eddies in the otherwise oxygenated tropical North Atlantic ${ }^{15}$, can induce substantial increases in $\mathrm{N}_{2} \mathrm{O}$ production and cause shifts in the $\mathrm{N}_{2} \mathrm{O}$ cycling pathways.

The OMZ in the North Atlantic Ocean is rather well ventilated, and lowest DO concentrations are around $40 \mu \mathrm{mol} \mathrm{kg} \mathrm{kg}^{-11,12}$. Recently, however, coherent mesoscale cyclonic eddies (CE) and anticyclonic mode water eddies (ACME) in the eastern tropical North Atlantic (ETNA), which form off the coast of west Africa along topographical features such as headlands, and then propagate westwards past the Cape Verde Islands ${ }^{16}$, have been shown to create extremely low DO concentrations (as low as $\sim 2 \mu \mathrm{mol} \mathrm{kg}{ }^{-1}$ ) 15 . The low DO concentrations inside the eddy have the potential to have important implications for biogeochemical processes, including

${ }^{1}$ GEOMAR Helmholtz Centre for Ocean Research Kiel, Kiel, Germany. ${ }^{2}$ Bermuda Institute of Ocean Sciences, Saint George's, Bermuda. ${ }^{3}$ University of Southern Denmark, Odense, Denmark. ${ }^{4}$ School for Marine Science and Technology, University of Massachusetts Dartmouth, Dartmouth, USA. Correspondence and requests for materials should be addressed to D.S.G. (email: damian.grundle@bios.edu) 


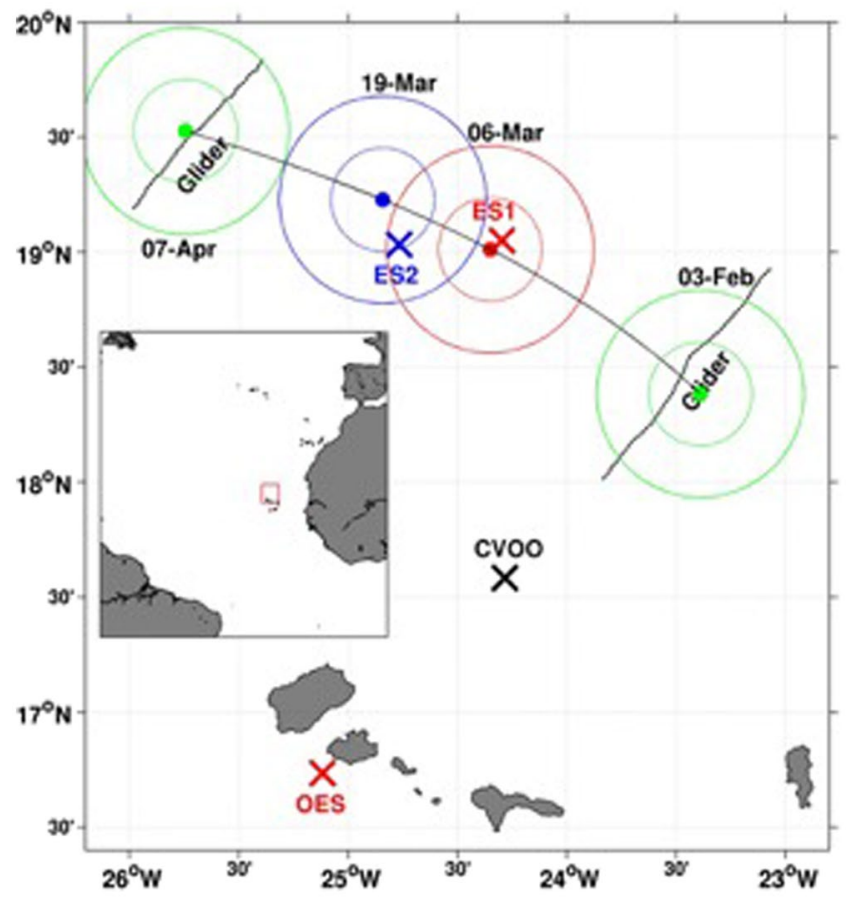

Figure 1. Locations of the relevant sampling sites. The Cape Verde Ocean Observatory (CVOO), outside eddy station (OES), eddy station 1 (ES1) and eddy station 2 (ES2) are marked with crosses, while the IFM12 and IFM13 glider surveys are indicated by dashed lines. The outer solid red and blue circles represent the position and area of the suboxic eddy during the ES1 and ES2 sampling events, respectively, while the outer solid green circles represent the location of the suboxic eddy during glider surveys (see description in Methods section). Note: the inner green, red and blue circles represent the area of the low DO core of the eddy. This map was created using Mathworks Matlab version R2014b (http://www.mathworks.com), and the coastline data are from the GSHHS (Global Self-consistent, Hierarchical, High-resolution Shorelines) data set published for free use by NOAA (https://www.ngdc.noaa.gov/mgg/shorlines/gshhs.html).

$\mathrm{N}_{2} \mathrm{O}$ cycling. Until recently, however, these potential implications have not been studied, as observations have been opportunistic and most have originated from moored and glider based sensors at the Cape Verde Ocean Observatory (CVOO; Fig. 1). In early 2014, however, a dedicated multi-disciplinary shipboard survey of one of these eddies (hereinafter referred to as 'suboxic eddy') was conducted. This survey allowed us to investigate how $\mathrm{N}_{2} \mathrm{O}$ cycling may be impacted by low oxygen eddies in the ETNA (sampling parameters and stations are outlined in the Methods section). The results from this work not only demonstrate the potential importance of low oxygen eddies as a source of $\mathrm{N}_{2} \mathrm{O}$, they also provide insights into how $\mathrm{N}_{2} \mathrm{O}$ cycling in the ETNA may respond to future DO decreases.

\section{Results and Discussion}

Dissolved oxygen and nitrous oxide concentrations. This study was part of a multi-disciplinary investigation of the suboxic eddy, and here we focus on the implications of the low DO concentrations inside the suboxic eddy for $\mathrm{N}_{2} \mathrm{O}$ processes. The physical characteristics of the eddy and other biological and biogeochemical processes are discussed elsewhere ${ }^{16-21}$. Sampling was conducted at two stations inside the eddy (eddy station 1 and 2; ES1 and ES2) and at an out-of-eddy reference station (OES; Fig. 1). Results show that the suboxic eddy was characterized by DO concentrations that were much lower than in the surrounding waters. For example, the lowest DO concentration we observed at OES was $72 \mu \mathrm{mol} \mathrm{L}^{-1}$ (Fig. 2a), and while this is somewhat higher than the lowest DO concentrations found in the ETNA $\left(\sim 40 \mu \mathrm{mol} \mathrm{kg}{ }^{-1}\right)$, it is within the range of the lowest DO concentrations often found in the region of the CVOO time-series station ${ }^{22}$. In contrast, the lowest DO concentrations at ES1 and ES2 were 10 and $5 \mu \mathrm{mol} \mathrm{L} \mathrm{L}^{-1}$, respectively, at $100 \mathrm{~m}$ (Fig. 2a). Glider surveys of the suboxic eddy also found lows of $\sim 5 \mu \mathrm{mol} \mathrm{O} \mathrm{L}^{-1}$ at $100 \mathrm{~m}$ depth (Fig. 3). The suboxic eddy sampled during this study was an ACME, and our observations of a shallow OMZ, with DO concentrations much lower than the 'typical' background conditions, are consistent with previous observations of low oxygen ACMEs and CEs which have transited through the CVOO time-series region ${ }^{15}$. The low oxygen conditions inside of these eddies likely result from increased remineralization below the mixed layer, resulting from high primary production and subsequent particulate matter export from the euphotic zone ${ }^{15,16}$. The high primary production is thought to be driven by enhanced upward vertical nutrient fluxes ${ }^{17}$. Indeed, in the suboxic eddy discussed here, mixed layer nutrient concentrations were higher inside vs. outside the eddy ${ }^{17}$, and primary production ${ }^{21}$ and particulate organic carbon fluxes ${ }^{20}$ were estimated to be up to three times higher inside the eddy compared to the surrounding waters. 


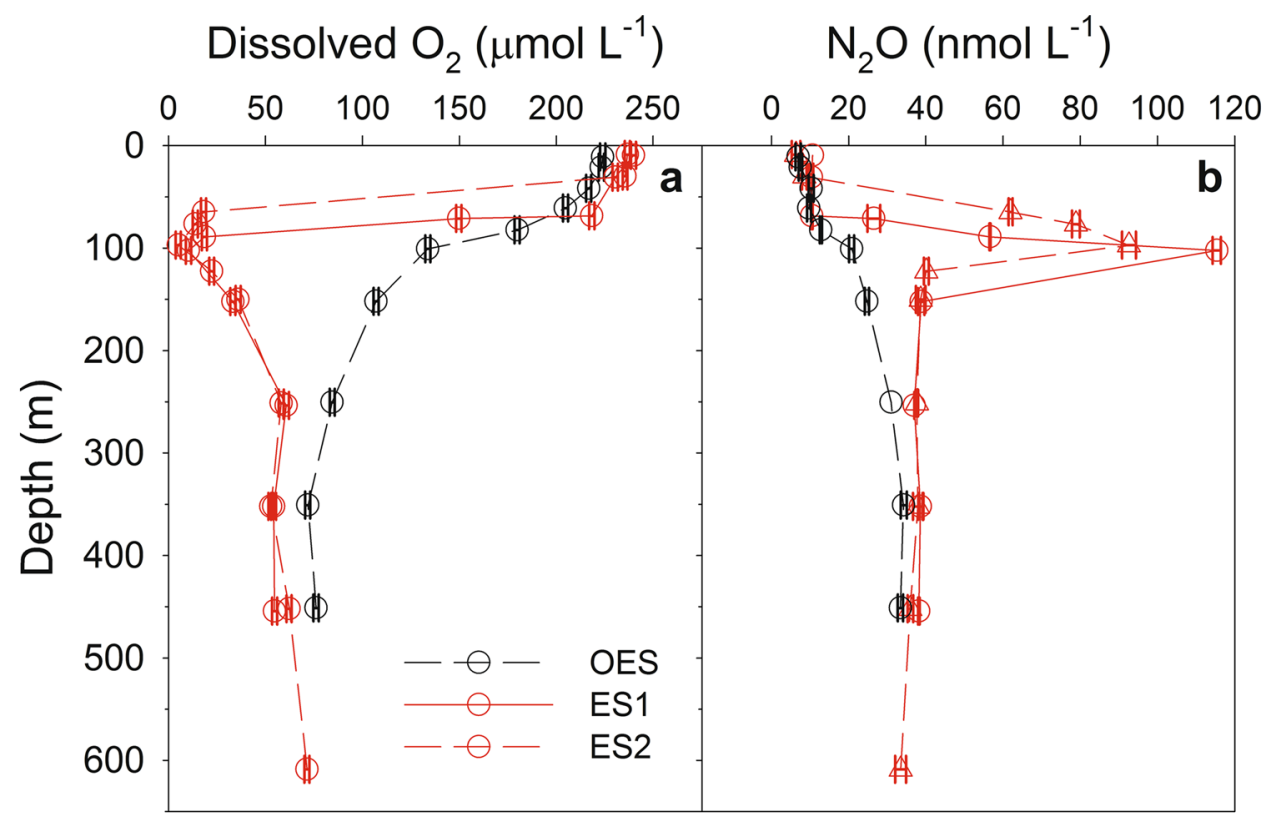

Figure 2. Vertical distributions of dissolved oxygen and $\mathrm{N}_{2} \mathrm{O}$ concentrations at the out-of-eddy station (OES), and at eddy stations 1 and 2 (ES1 and ES2, respectively). (a) Discrete depth dissolved oxygen (DO) concentrations measured with the CTD-DO sensor at each of our sampling depths. The error bars represent the average propagation of error associated with our DO measurements (see Methods section). (b) Discrete depth $\mathrm{N}_{2} \mathrm{O}$ concentrations. The error bars represent the standard deviation of duplicate $\mathrm{N}_{2} \mathrm{O}$ concentration measurements. Due to the loss of duplicated samples, standard deviations are not reported for $10 \mathrm{~m}$ depth at ES1, and $250 \mathrm{~m}$ depth at OES.

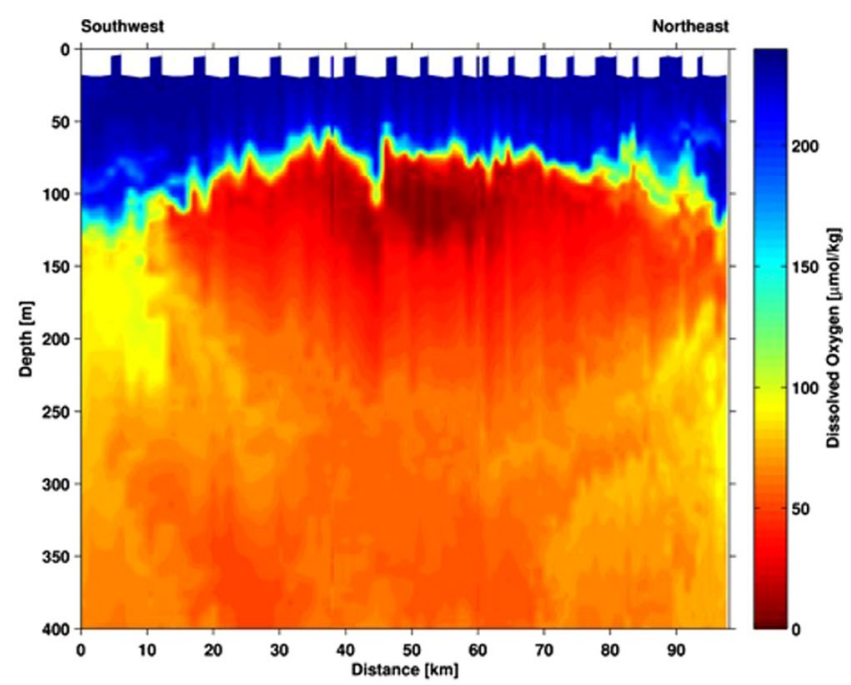

Figure 3. Dissolved oxygen concentrations as measured during the IFM13 glider survey on April $7^{\text {th }}, 2014$.

Similar to the DO results, we observed large perturbations to the $\mathrm{N}_{2} \mathrm{O}$ conditions inside vs. outside of the suboxic eddy. The highest $\mathrm{N}_{2} \mathrm{O}$ concentration at OES $\left(34.2 \mathrm{nmol} \mathrm{L}^{-1}\right.$; Fig. $\left.2 \mathrm{~b}\right)$ was within the range of the highest concentrations previously reported for the North Atlantic ${ }^{14,23}$, but somewhat lower than the highest concentration found in the eastern tropical South Atlantic $\left(49 \mathrm{nmol} \mathrm{L}^{-1}\right)^{24}$. Corresponding to the vertical depth range of low $\mathrm{DO}, \mathrm{N}_{2} \mathrm{O}$ concentrations much higher than those previously reported for the North Atlantic were found inside the suboxic eddy, with values as high as $115 \mathrm{nmol} \mathrm{L}^{-1}$ within the ES1 OMZ (100 m depth; Fig. 2b). The high $\mathrm{N}_{2} \mathrm{O}$ concentrations we observed in the core of the suboxic eddy are within the range of many of the highest values reported for the eastern tropical Pacific ${ }^{25-29}$ and open Arabian Sea ${ }^{30,31}$, although concentrations as high as up to $\sim 500 \mathrm{nmol} \mathrm{N}_{2} \mathrm{O} \mathrm{L} \mathrm{L}^{-1}$ have been reported for the coastal regions of the eastern tropical South Pacific off of Chile ${ }^{32}$. The observations reported here demonstrate that $\mathrm{N}_{2} \mathrm{O}$ concentrations within ETNA suboxic eddies can reach levels comparable to those from regions that are characterized by well defined OMZs where DO concentrations 

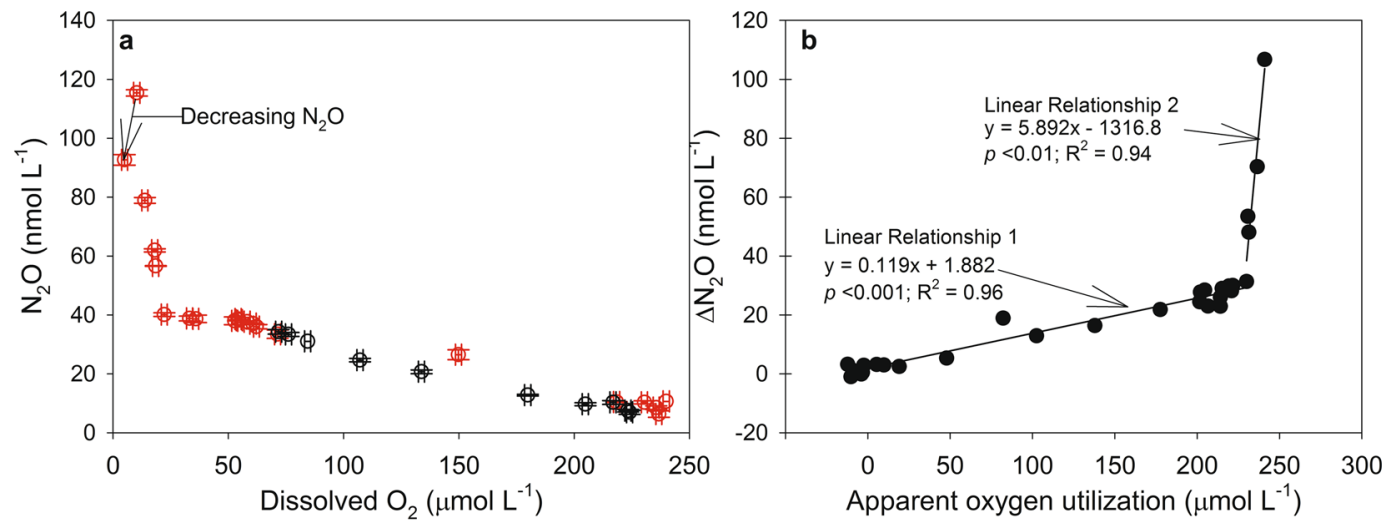

Figure 4. Relationship between nitrous oxide and dissolved oxygen (DO) parameters. (a) Nitrous oxide vs. DO concentrations from ES1 and ES2 (red circles) and from OES (black circles). The X-axis error bars represent the average propagation of error associated with our DO measurements (see Methods section) and the y-axis error bars represent the standard deviation of duplicate $\mathrm{N}_{2} \mathrm{O}$ concentration measurements. (b) $\Delta \mathrm{N}_{2} \mathrm{O}$ vs. apparent oxygen utilization (all data pooled; note: data point from the DO minimum at ES2 where the $\mathrm{N}_{2} \mathrm{O}$ concentration decreased is omitted). The solid lines are linear regressions and the results from the linear regression analyses are included.

are permanently low (e.g. eastern tropical Pacific and Arabian Sea), and which are considered to be major sources of oceanic $\mathrm{N}_{2} \mathrm{O}$. To this end, low oxygen eddies in the ETNA may prove to be an important but previously unrecognized source of $\mathrm{N}_{2} \mathrm{O}$.

A plot of all $\mathrm{N}_{2} \mathrm{O}$ and DO concentration data showed these two variables to be inversely correlated down to a DO concentration of $10 \mu \mathrm{mol} \mathrm{L}^{-1}$ (Fig. 4a). Between 10 and $5 \mu \mathrm{mol} \mathrm{O}_{2} \mathrm{~L}^{-1}$, however, this trend appears that it may have begun to reverse as the $\mathrm{N}_{2} \mathrm{O}$ concentration decreased from 115 to $92.7 \mathrm{nmol} \mathrm{L}^{-1}$ (Fig. $4 \mathrm{a}$ ). It is important to note that the observation of a decrease in $\mathrm{N}_{2} \mathrm{O}$ concentration between 10 and $5 \mu \mathrm{mol} \mathrm{O}_{2} \mathrm{~L}^{-1}$ was based on sampling conducted almost two weeks apart, and, as such, the decrease may have been due to $\mathrm{N}_{2} \mathrm{O}$ diffusing out of the DO minimum $/ \mathrm{N}_{2} \mathrm{O}$ maximum in the period between our two sampling events. If $\mathrm{N}_{2} \mathrm{O}$ was diffusing across a high to low concentration gradient, then DO would have also likely been diffusing from high to low concentrations (i.e. into the DO minimum), and this would have started to erode the extremely low DO concentrations we observed. A glider survey of the eddy on April $7^{\text {th }} 2014$ (i.e. three weeks after our ES2 sampling date) showed that the low DO eddy core was still stable and intact (Fig. 3). To this end, it seems unlikely that diffusion was a major contributor to the decrease in $\mathrm{N}_{2} \mathrm{O}$ we observed between 10 and $5 \mu \mathrm{mol} \mathrm{O}_{2} \mathrm{~L}^{-1}$. A shift from net $\mathrm{N}_{2} \mathrm{O}$ production to net $\mathrm{N}_{2} \mathrm{O}$ consumption is another possible explanation for the decrease in $\mathrm{N}_{2} \mathrm{O}$ concentrations between 10 and $5 \mu \mathrm{mol} \mathrm{O}{ }_{2} \mathrm{~L}^{-1}$. It is important to note, however, that the suggestion of a switch from net $\mathrm{N}_{2} \mathrm{O}$ production to net $\mathrm{N}_{2} \mathrm{O}$ consumption should be treated with caution given that it is based on a single observation of $\mathrm{N}_{2} \mathrm{O}$ decreasing between 10 and $5 \mu \mathrm{mol} \mathrm{O} \mathrm{L}^{-1}$. Still, it is not an unreasonable proposition as previous results have also shown evidence for a transition from net production to net consumption below $10 \mu \mathrm{mol} \mathrm{O}_{2} \mathrm{~L}^{-133}$.

At DO concentrations $\geq 10 \mu \mathrm{mol} \mathrm{L}-1$, a plot of $\Delta \mathrm{N}_{2} \mathrm{O}\left(\left[\mathrm{N}_{2} \mathrm{O}_{\text {measured }}\right]-\left[\mathrm{N}_{2} \mathrm{O}_{\text {saturation }}\right]\right)$ vs. AOU (apparent oxygen utilization; $\left[\mathrm{O}_{2}\right.$, measured $]-\left[\mathrm{O}_{2}\right.$, saturation $]$ ) shows two distinct linear relationships (Fig. 4b). Linear relationship 1 (LR1) and 2 (LR2) correspond to DO concentration ranges of 240 to $22 \mu \mathrm{mol} \mathrm{L}^{-1}$ and 18 to $10 \mu \mathrm{mol} \mathrm{L}^{-1}$, respectively. The slope of LR1 (Fig. $4 \mathrm{~b}$ ) indicates that $\sim 8500 \mathrm{~mol}_{\text {of }} \mathrm{O}_{2}$ were consumed for every mol of $\mathrm{N}_{2} \mathrm{O}$ produced, and this is similar to previous estimates from the open tropical Atlantic Ocean ${ }^{13,14}$, including the Mauritanian upwelling region ${ }^{23}$; it is also similar to estimates from global oxygenated oceanic water masses ${ }^{8,9,29}$. In contrast, the slope of LR2 implies that only $170 \mathrm{~mol}$ of $\mathrm{O}_{2}$ were consumed for every mol of $\mathrm{N}_{2} \mathrm{O}$ produced, and this points towards a 50-fold increase in the amount of $\mathrm{N}_{2} \mathrm{O}$ produced vs. the amount of DO consumed below $20 \mu \mathrm{mol} \mathrm{O}_{2}$ $\mathrm{L}^{-1}$. This result agrees with Codispoti et al. ${ }^{34}$ and Nevison et al. ${ }^{29}$ who also showed that $\mathrm{N}_{2} \mathrm{O}$ production starts to increase substantially below $\sim 20 \mu \mathrm{mol} \mathrm{O}_{2} \mathrm{~L}^{-1}$. Our estimate of a 50 -fold increase in $\mathrm{N}_{2} \mathrm{O}$ production vs. DO consumption is, however, higher than results from earlier work which have shown that nitrification- $\mathrm{N}_{2} \mathrm{O}$ yields can increase 20 -fold ${ }^{10}$ and 40 -fold ${ }^{35}$ under low DO concentrations. One possible explanation for our observation of higher $\mathrm{N}_{2} \mathrm{O}$ production vs. DO consumption could be the presence of $\mathrm{N}_{2} \mathrm{O}$ production via reductive pathways (i.e. sources of $\mathrm{N}_{2} \mathrm{O}$ production which do not also consume $\mathrm{DO}$ ), and evidence for this is discussed below under 'Nitrous oxide cycling pathways'.

Finally, simple linear regression analyses were used to quantify the $\mathrm{N}_{2} \mathrm{O}$ vs. DO relationships shown in Fig. 4a at DO concentrations between 250 and $20 \mu \mathrm{mol} \mathrm{L}^{-1},<20$ and $10 \mu \mathrm{mol} \mathrm{L}^{-1}$, and $<10 \mu \mathrm{mol} \mathrm{L}^{-1}$ (Table 1). These DO ranges were selected based on the observed $\mathrm{N}_{2} \mathrm{O}$ vs. DO shifts shown in Fig. 4a. The $\mathrm{N}_{2} \mathrm{O}$ vs. DO relationships for each of these DO ranges were then applied to the DO concentrations observed during the high resolution IFM13 glider survey in order to estimate the bulk amount of $\mathrm{N}_{2} \mathrm{O}$ inside the suboxic eddy core. Based on the DO concentrations measured during the glider survey (Fig. 3), the diameter of the suboxic eddy core was defined as $50 \mathrm{~km}$ and extended from the surface to $250 \mathrm{~m} \mathrm{depth}$, and the bulk amount of $\mathrm{N}_{2} \mathrm{O}$ within this volume was estimated to have been $1.8 \times 10^{7} \mathrm{~mol} \mathrm{~N}_{2} \mathrm{O}$, or an average of $9,200 \mathrm{~mol} \mathrm{~N}_{2} \mathrm{O} \mathrm{km}^{-2}$. In comparison, areal $\mathrm{N}_{2} \mathrm{O}$ over the same depth range at OES was $5,000 \mathrm{~mol} \mathrm{~N}_{2} \mathrm{O} \mathrm{km}$, or almost half that within the suboxic eddy core. This 


\begin{tabular}{|c|c|c|c|}
\hline $\begin{array}{l}\text { Dissolved } \mathrm{O}_{2} \\
\text { Concentration Range }\end{array}$ & $\begin{array}{l}\mathrm{N}_{2} \mathrm{O}\left(\mathrm{nmol} \mathrm{L}^{-1}\right) \text { vs. } \mathrm{O}_{2}\left(\mu \mathrm{mol} \mathrm{L} \mathrm{L}^{-1}\right) \\
\text { Linear Regression Equation }\end{array}$ & $p$-value & $\mathbf{R}^{2}$-value \\
\hline $250-\geq 20 \mu \mathrm{mol} \mathrm{L}^{-1}$ & $\mathrm{~N}_{2} \mathrm{O}_{\text {conc. }}=-0.162 \times \mathrm{O}_{2 \text { conc. }}+45.48$ & $<0.001$ & 0.97 \\
\hline$<20-10 \mu \mathrm{mol} \mathrm{L}{ }^{-1}$ & $\mathrm{~N}_{2} \mathrm{O}_{\text {conc. }}=-6.67 \times \mathrm{O}_{2 \text { conc. }}+179.04$ & 0.03 & 0.95 \\
\hline $10-5 \mu \mathrm{mol} \mathrm{L}^{-1}$ & $\mathrm{~N}_{2} \mathrm{O}_{\text {conc. }}=4.30 \times \mathrm{O}_{2 \text { conc. }}+71.28$ & - & - \\
\hline
\end{tabular}

Table 1. Results from simple linear regression analyses of $\mathrm{N}_{2} \mathrm{O}$ vs. DO at different $\mathrm{DO}$ concentration ranges. The results shown here were obtained using data shown in Fig. 2a. The regression equations were used in conjunction with the DO concentrations measured during the IFM13 glider survey of the eddy (see Methods section) in order to estimate the bulk amount of $\mathrm{N}_{2} \mathrm{O}$ inside the suboxic eddy.

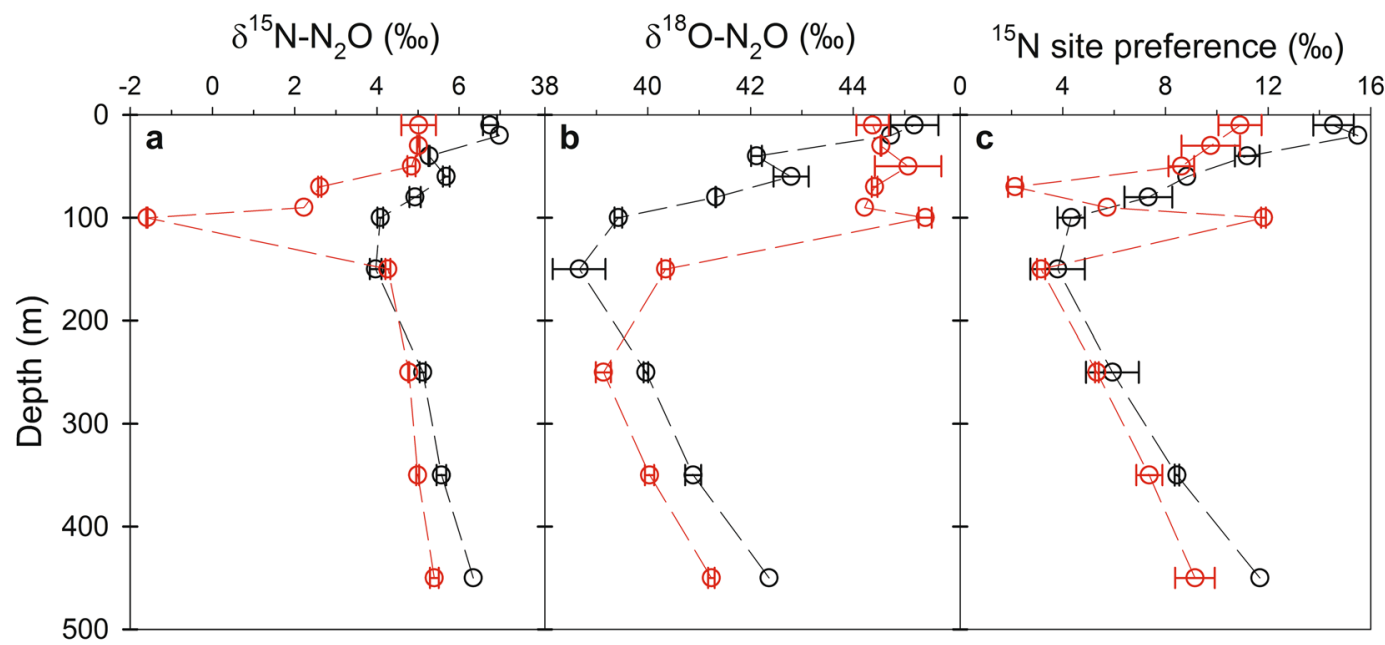

Figure 5. Vertical distributions of $\left(\right.$ a) $\delta{ }^{15} \mathrm{~N}-\mathrm{N}_{2} \mathrm{O},(\mathbf{b}) \delta^{18} \mathrm{O}-\mathrm{N}_{2} \mathrm{O}$ and $(\mathbf{c}){ }^{15} \mathrm{~N}$ site preference signatures at ES1 (red circles) and OES (black circles). Error bars represent the standard deviation of duplicate $\mathrm{N}_{2} \mathrm{O}$ isotope measurements. Due to the loss of duplicated samples, standard deviations are not reported for 20 and $450 \mathrm{~m}$ depth at OES, and $90 \mathrm{~m}$ depth at ES1.

again highlights that low oxygen eddies have the potential to be important but previously unrecognized sources of marine $\mathrm{N}_{2} \mathrm{O}$. Quantifying the overall importance of low oxygen eddies is not trivial, however, and it would depend, for example, on factors such as the frequency of their occurrence, their size, and how long they last ${ }^{16,36}$. A recent analysis of a $1.1 \times 10^{6} \mathrm{~km}^{2}$ area of the ETNA suggests that at any one time $\sim 20 \%$ of this area is covered by suboxic eddy cores ${ }^{16}$. Assuming all of these suboxic eddy cores are similar to the one described here, which showed an almost $100 \%$ increase in $\mathrm{N}_{2} \mathrm{O}$ concentrations inside vs. outside of the eddy, this could require bulk upper water column (in this case upper $250 \mathrm{~m}$ ) $\mathrm{N}_{2} \mathrm{O}$ estimates to be increased by up to $20 \%$. This is a first order estimate, however, and much more shipboard work is necessary to accurately determine the $\mathrm{DO}$ and $\mathrm{N}_{2} \mathrm{O}$ conditions within a range of ETNA eddies, and covering their full lifecycles, so that more robust statistical analyses of their potential importance as a source of marine $\mathrm{N}_{2} \mathrm{O}$ can be calculated. Furthermore, if the prevalence of suboxic eddies are also found to be high outside of the ETNA, these types of low oxygen events may be found to be important at the global scale, rather than just the regional scale.

Nitrous oxide cycling pathways. Results from isotope and isotopomer (i.e. the intramolecular distribution of ${ }^{15} \mathrm{~N}$ within the linear NNO molecule; $\delta^{15} \mathrm{~N}^{\alpha}-\delta^{15} \mathrm{~N}^{\beta}$ ) measurements, as well as molecular genetic analyses, point towards shifts in the $\mathrm{N}_{2} \mathrm{O}$ cycling pathways in the core of the suboxic eddy, relative to the more oxygenated waters inside and outside of the eddy. This complete suite of isotope, isotopomer $\left({ }^{15} \mathrm{~N}\right.$ site-preference; $\left.\mathrm{SP}\right)$ and molecular genetic sampling was not conducted at ES2, so our discussion focuses on ES1 with comparisons to OES. At OES, vertical profiles of $\delta^{15} \mathrm{~N}^{\text {bulk }}-\mathrm{N}_{2} \mathrm{O}, \delta^{18} \mathrm{O}-\mathrm{N}_{2} \mathrm{O}$ and SP (Fig. 5) were characteristic of those from regions of the tropical South Atlantic, indicating that $\mathrm{N}_{2} \mathrm{O}$ was produced by a combination of $\mathrm{AO}$ and nitrifier-denitrification ${ }^{24}$. The $\delta^{15} \mathrm{~N}^{\text {bulk }}-\mathrm{N}_{2} \mathrm{O}$ :SP ratios were also within the range of those reported for $\mathrm{N}_{2} \mathrm{O}$ produced via nitrification processes ${ }^{28}$. Furthermore, gene copy numbers and transcripts, which provide an indication of gene abundance and expression, respectively, of $a m o A$ and nirS genes can also provide insight into the potential $\mathrm{N}_{2} \mathrm{O}$ cycling pathways. The $a m o A$ gene is the classical functional marker gene encoding for a subunit of the ammonia monooxygenase enzyme which catalyzes $\mathrm{AO}$, and a correlation between $\mathrm{N}_{2} \mathrm{O}$ formation by $\mathrm{AO}$ and $a m o A$ gene expression has been previously demonstrated ${ }^{37,38}$. To this end, we consider it reasonable to connect at least the potential for $\mathrm{N}_{2} \mathrm{O}$ formation to amoA abundance and expression. In contrast, the nirS gene encodes for the enzyme involved in $\mathrm{NO}_{2}{ }^{-}$reduction via the denitrification pathway, and recent results have shown a positive relationship between the abundance of nirS genes and $\mathrm{N}_{2} \mathrm{O}$ production by denitrification ${ }^{35}$. At OES, 


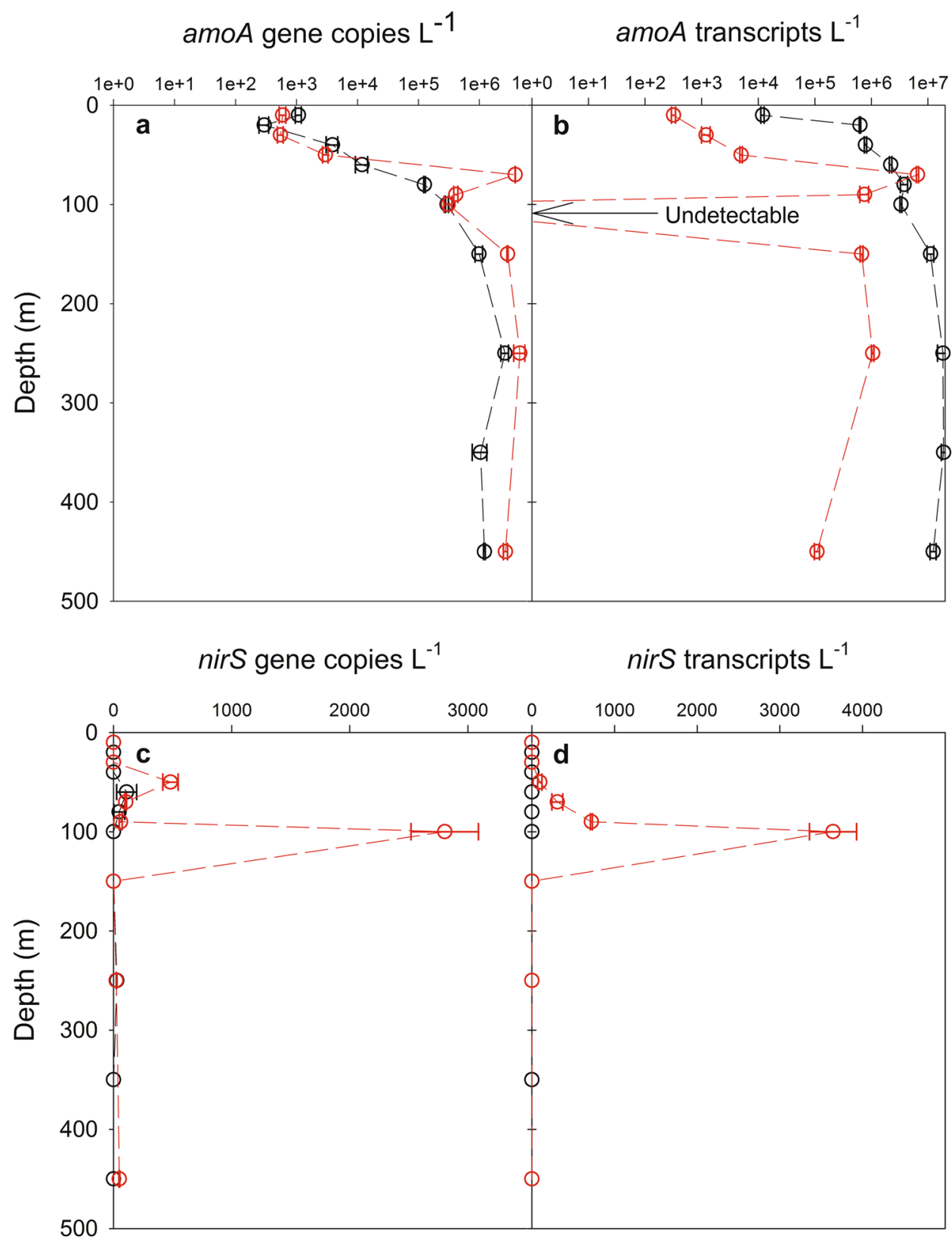

Figure 6. Vertical distributions of (a) amoA gene copies, (b) amoA transcripts, (c) nirS gene copies and (d) nirS transcripts at ES1 (red circles) and OES (black circles). The error bars represent the standard deviation of duplicate measurements. Note: the amoA and nirS gene data were also included in a description of the microbial community within the eddy by Löscher et al. ${ }^{21}$.

amoA gene abundance and expression (Fig. 6a,b) were considerably higher than that of the nirS gene (Fig. 6c,d). This supports our assertion that nitrification was the major source of $\mathrm{N}_{2} \mathrm{O}$ within the oxygenated waters of OES, and it is consistent with previous studies in this region ${ }^{13}$. Similarly, above and below the ES1 DO minimum, nitrification processes also appear to be the predominant source of $\mathrm{N}_{2} \mathrm{O}$, as $\delta^{15} \mathrm{~N}^{\text {bulk }}-\mathrm{N}_{2} \mathrm{O}$ and SP ratios were again within the range expected for $\mathrm{N}_{2} \mathrm{O}$ produced by nitrifiers ${ }^{28}$, and $a m o A$ gene abundance and expression were high. The SP signatures above and below the ES1 DO minimum were, however, in some cases somewhat lower than those found at OES (Fig. 5c). Both nitrifier-denitrification and denitrification yield $\mathrm{N}_{2} \mathrm{O}$ with an SP $\leq 0 \%$, whereas $\mathrm{AO}$ yields $\mathrm{N}_{2} \mathrm{O}$ with an $\mathrm{SP}>30 \%{ }^{4,39,40}$. The SP observations therefore indicate that a reductive pathway (i.e. nitrifier-denitrification or denitrification), rather than an oxidative pathway, was a relatively more important source of $\mathrm{N}_{2} \mathrm{O}$ at ES1 vs. OES. Given that amoA gene abundance was high above and below the ES1 DO minimum, whereas nirS gene abundance and expression were either undetectable or very low, we suggest that nitrifier-denitrification was the most probable reductive $\mathrm{N}_{2} \mathrm{O}$ production pathway above and below the ES1 DO minimum. The potential increase in $\mathrm{N}_{2} \mathrm{O}$ production via nitrifier-denitrification at ES1, when compared to OES, 
was likely a result of the lower DO concentrations inside vs. outside of the suboxic eddy, as culture investigations have shown that nitrifier-denitrification increases as DO concentrations decrease ${ }^{4}$.

Differences in isotope and molecular genetic results inside vs. outside of the suboxic eddy were most prominent within the ES1 DO minimum at $100 \mathrm{~m}$, and our results provide insights into how $\mathrm{N}_{2} \mathrm{O}$ cycling changed as the DO concentration dropped to $\sim 10 \mu \mathrm{mol} \mathrm{L}{ }^{-1}$. One of the most prominent differences was the $\delta^{15} \mathrm{~N}^{\text {bulk }}-\mathrm{N}_{2} \mathrm{O}$ value, which decreased to $-1.6 \%$ within the ES1 OMZ. This is below the lowest value reported for the Arabian $\mathrm{Sea}^{31}$, and is one of the lowest values reported for seawater, one exception being the Black Sea where a value of $-10.8 \%$ was observed ${ }^{41}$. Westley et al. ${ }^{41}$ concluded that this ${ }^{15} \mathrm{~N}^{\text {bulk }}-\mathrm{N}_{2} \mathrm{O}$ value of $-10.8 \%$ was too low to have been caused by a reductive $\mathrm{N}_{2} \mathrm{O}$ production pathway, and instead they concluded that it must have been caused by $\mathrm{N}_{2} \mathrm{O}$ produced via $\mathrm{AO}$. Although very low for seawater, the $\delta^{15} \mathrm{~N}^{\text {bulk }}-\mathrm{N}_{2} \mathrm{O}$ value we observed within the ES1 DO minimum was not as extreme as that of Westley et al. ${ }^{41}$, and taken alone it cannot be used to narrow down the predominant production pathway. That is, based on the $\delta^{15} \mathrm{~N}$ signatures of dissolved inorganic nitrogen from the eastern tropical Atlantic ${ }^{13}$, and the range of measured isotope effects of nitrification and denitrification (summarized by Bange $)^{2}$, the $\delta^{15} \mathrm{~N}^{\text {bulk }}-\mathrm{N}_{2} \mathrm{O}$ value from the ES1 DO minimum could have been produced by either oxidative or reductive pathways. Our molecular genetic results, however, provide further insight into the potential predominant $\mathrm{N}_{2} \mathrm{O}$ production pathway. The abundance and expression of nirS genes increased substantially within the ES1 OMZ (Fig. 6c,d), and these results, particularly the increase in nirS gene expression, suggest that denitrification was actively occurring at the ES1 DO minimum. In contrast, although amoA gene abundance was still relatively high (Fig. 6a), the expression of amoA genes became undetectable within the ES1 DO minimum (Fig. 6b), thus indicating a substantial reduction in $\mathrm{N}_{2} \mathrm{O}$ production via AO. Ultimately, our molecular genetic results provide evidence that implies that denitrification became an important source of $\mathrm{N}_{2} \mathrm{O}$ within the ES1 DO minimum. Our suggestion that denitrification was an important source of $\mathrm{N}_{2} \mathrm{O}$ at DO concentrations $\sim 10 \mu \mathrm{molL}^{-1}$ (i.e. ES1 OMZ) is also supported by a recent modelling study ${ }^{25}$ and by ${ }^{15} \mathrm{~N}$ tracer measurements ${ }^{35}$ which found that denitrification was an important source of $\mathrm{N}_{2} \mathrm{O}$ at similar DO concentrations.

While it appears that denitrification was an important source of $\mathrm{N}_{2} \mathrm{O}$ within the ES1 OMZ, two lines of evidence point towards the potential for at least partial $\mathrm{N}_{2} \mathrm{O}$ consumption by denitrification. Firstly, in comparison to the more oxygenated waters directly above and below it, the $\delta^{15} \mathrm{~N}^{\text {bulk }}-\mathrm{N}_{2} \mathrm{O}$ and $\delta^{18} \mathrm{O}-\mathrm{N}_{2} \mathrm{O}$ values at the ES1 DO minimum decreased and increased, respectively (Fig. 5a,b). The observation of a concomitant $\delta^{15} \mathrm{~N}^{\text {bulk }}-\mathrm{N}_{2} \mathrm{O}$ decrease and $\delta^{18} \mathrm{O}-\mathrm{N}_{2} \mathrm{O}$ increase is extremely rare, however, it has been observed in the Black Sea where it was interpreted as indicating simultaneous $\mathrm{N}_{2} \mathrm{O}$ production and consumption (i.e. a production source which decreases $\delta^{15} \mathrm{~N}^{\text {bulk }}-\mathrm{N}_{2} \mathrm{O}$ and a consumption sink which increases $\left.\delta^{18} \mathrm{O}-\mathrm{N}_{2} \mathrm{O}\right)^{41}$. Secondly, a notable SP increase was also observed in the ES1 DO minimum (Fig. 5c). Similar to nitrifier-denitrification, production of $\mathrm{N}_{2} \mathrm{O}$ by denitrification yields $\mathrm{N}_{2} \mathrm{O}$ with an $\mathrm{SP} \leq 0 \%$, while AO produces $\mathrm{N}_{2} \mathrm{O}$ with an $\mathrm{SP} \geq 30 \%{ }^{4,39,40}$. As such, an initial interpretation of the SP result by itself could point towards a larger contribution of $\mathrm{N}_{2} \mathrm{O}$ via the AO route. Given the extremely reduced expression of $a m o A$ genes in the ES1 DO minimum, however, this seems unlikely. Instead, reduction of $\mathrm{N}_{2} \mathrm{O}$ to $\mathrm{N}_{2}$ can also result in an SP increase, albeit a highly variable one ${ }^{42-44}$, and results have shown that the reduction of $\mathrm{N}_{2} \mathrm{O}$ can cause $\mathrm{SP}$ to increase even when there are net $\mathrm{N}_{2} \mathrm{O}$ gains ${ }^{45}$. Based on the simultaneous $\delta^{15} \mathrm{~N}^{\text {bulk }}-\mathrm{N}_{2} \mathrm{O}$ decrease and $\delta^{18} \mathrm{O}-\mathrm{N}_{2} \mathrm{O}$ increase, and the increased SP signature, we therefore propose that some of the $\mathrm{N}_{2} \mathrm{O}$ produced within the ES1 DO minimum was subsequently reduced to $\mathrm{N}_{2}$.

Although limited in scope, this is the first study to show evidence which points towards $\mathrm{N}_{2} \mathrm{O}$ cycling by denitrification in the open Atlantic Ocean. As outlined earlier, $20 \%$ of the ETNA is covered by low oxygen eddy cores at any one time; as such, if denitrification is also cycling $\mathrm{N}_{2} \mathrm{O}$ in these other low oxygen eddies, we may need to change our classical view that $\mathrm{N}_{2} \mathrm{O}$ cycling in the ETNA is restricted to nitrification. It is, however, important to point out that while we have suggested that denitrification played a role in cycling $\mathrm{N}_{2} \mathrm{O}$ within the suboxic eddy investigated during this study, it only appears to be important at the nanomolar scale (i.e. the scale at which we measure $\mathrm{N}_{2} \mathrm{O}$ ), as at the micromolar scale there was no evidence for $\mathrm{NO}_{3}{ }^{-}$reduction ${ }^{20}$ or biogenic $\mathrm{N}_{2}$ production (Altabet and Grundle, unpublished data) inside the suboxic eddy. Still, some of the low oxygen eddies which have been observed in the ETNA with moored and glider based instruments have been characterized by DO concentrations even lower than those reported here ${ }^{15}$, and to this end, it is possible that some of the low oxygen eddies in the ETNA may also be sites of fixed $\mathrm{N}$ losses at the micromolar scale.

\section{Summary}

The present study has demonstrated for the first time that low DO eddies in the eastern tropical North Atlantic can cause significant shifts in the $\mathrm{N}_{2} \mathrm{O}$ cycling dynamics which are typically found in this region. Furthermore, this work has shown that low DO eddies can serve as ideal 'natural laboratories' for investigating the impact of decreasing DO concentrations for marine $\mathrm{N}_{2} \mathrm{O}$ conditions. In the case of this study, our results showed that at DO concentrations $<\sim 20 \mu \mathrm{mol} \mathrm{L}^{-1}, \mathrm{~N}_{2} \mathrm{O}$ production increased substantially, resulting in concentrations which were within the range of many of the highest $\mathrm{N}_{2} \mathrm{O}$ concentrations reported for major OMZ regions such as the open Arabian Sea and eastern tropical Pacific. This result has demonstrated the magnitude by which $\mathrm{N}_{2} \mathrm{O}$ production could increase if open ocean DO concentrations decrease in the tropical Atlantic. Isotope and molecular genetic results also provided evidence for a major shift in the $\mathrm{N}_{2} \mathrm{O}$ cycling pathways at $\sim 10 \mu \mathrm{mol} \mathrm{O} \mathrm{O}_{2}^{-1}$, such that it appeared that denitrifcation not only started to produce $\mathrm{N}_{2} \mathrm{O}$, it also started to partially consume some of the $\mathrm{N}_{2} \mathrm{O}$. Finally, as DO concentrations decreased to $\sim 5 \mu \mathrm{mol} \mathrm{L} \mathrm{L}^{-1}$ the $\mathrm{N}_{2} \mathrm{O}$ concentration also decreased, possibly indicating a switch from net $\mathrm{N}_{2} \mathrm{O}$ production to net $\mathrm{N}_{2} \mathrm{O}$ consumption. Ultimately, given that this study has shown the capacity of low DO eddies to be $\mathrm{N}_{2} \mathrm{O}$ production 'hotspots', and because $\mathrm{N}_{2} \mathrm{O}$ cycling pathways (i.e. denitrification) not previously thought to occur in the Atlantic were observed, a reevaluation of $\mathrm{N}_{2} \mathrm{O}$ budgets and cycling in the tropical Atlantic Ocean may be necessary. 


\begin{abstract}
Methods
Glider Surveys. Two Slocum gliders (IFM12 and IFM13) manufactured by Teledyne Webb Research were used in this study to observe the temperature, salinity, dissolved oxygen and current fields north of the Cape Verde archipelago. Between January and April 2014, these gliders were able to confirm the presence of an anti-cylconic mode-water eddy, which had formed off the coast of Mauritania and then propagated westward toward the Cape Verde Ocean Observatory (CVOO; Fig. 1). IFM12 was deployed on January $10^{\text {th }}, 2014$ from the Cape Verdean RV Islandia, and it first entered the eddy reported here on January $23^{\text {rd }}, 2014$. A first section through the eddy core was completed by IFM12 on February $3^{\text {rd }} 2014$, and results confirmed that it was a low DO eddy. IFM13 was deployed from RV Meteor on March 17 $7^{\text {th }}, 2014$ and completed a section through the eddy core on April $7^{\text {th }}$, 2014. The data collected by the gliders underwent post-processing routines that included a glider-speed dependent thermal lag correction of the conductivity cell ${ }^{46}$, and a mixed lab/in-situ calibration of the Aanderaa Optode oxygen sensor. Finally, the locations of the eddy during the IFM12 and IFM13 deployments, and the locations of the glider sections are shown in Fig. 1, and DO concentrations from the IFM13 section through the eddy are shown in Fig. 3.
\end{abstract}

Ship-Based Sampling. Between March $6^{\text {th }}$ and $7^{\text {th }} 2014$, the RV Islandia was used to conduct sampling for a suite of biological, chemical and physical parameters at a station inside the suboxic eddy (eddy station 1; Fig. 1). In order to allow for comparisons between measurements made inside the eddy with conditions outside the eddy, the same suite of samples collected at eddy station 1 (ES1) were also collected at an outside eddy station (OES) during an RV Islandia cruise on February $14^{\text {th }} 2014$ (Fig. 1). Here we outline the sampling and measurements of parameters that relate to $\mathrm{N}_{2} \mathrm{O}$ cycling.

Dissolved oxygen (DO) concentrations were measured using a Seabird SBE43 DO sensor that was attached to our conductivity, temperature and depth (CTD) profiler. The DO sensor was calibrated using DO measurements by Winkler titration on duplicated samples collected across the entire range of DO concentrations observed. The detection limit of these measurements was $3 \mu \mathrm{mol} \mathrm{O} \mathrm{L}^{-1}$, and the average standard deviation of the duplicate measurements was $\pm 0.28 \mu \mathrm{mol} \mathrm{O}_{2} \mathrm{~L}^{-1}$. It is important to note, however, that in order to preserve Niskin bottle water for our $\mathrm{N}_{2} \mathrm{O}$ concentration and isotope samples, bottle samples for DO measurements by Winkler titration were not collected on our $\mathrm{N}_{2} \mathrm{O}$ vertical sampling casts. Samples for DO measurements by Winkler titration, for the purpose of calibrating the DO sensor, were instead collected on CTD casts immediately before and after our $\mathrm{N}_{2} \mathrm{O}$ sampling casts. The average standard deviation between our discrete Winkler DO measurements and our calibrated CTD-DO sensor measurements was $\pm 1.31 \mu \mathrm{mol} \mathrm{O}_{2} \mathrm{~L}^{-1}$. Considering the errors involved in both our duplicated Winkler DO measurements $\left( \pm 0.28 \mu \mathrm{mol} \mathrm{O}_{2} \mathrm{~L}^{-1}\right)$ and our CTD-DO measurements $( \pm 1.31 \mu \mathrm{mol}$ $\mathrm{O}_{2} \mathrm{~L}^{-1}$ ), the average propagation of error associated with the DO concentrations we report for eddy station 1 is $\pm 1.33 \mu \mathrm{mol} \mathrm{O}_{2} \mathrm{~L}^{-1}$. Discrete depth water samples were also collected from the surface to $450 \mathrm{~m}$ depth for the purpose of measuring $\mathrm{N}_{2} \mathrm{O}$ concentrations, isotope and isotopomer signatures of $\mathrm{N}_{2} \mathrm{O}$, and for quantifying the abundance and transcripts of ammonia-monooxygenase genes of nitrifying bacteria and archaea, and nitrite reductase genes of denitrifying bacteria ( $a m o A$ and nirS, respectively; all protocols described below).

On March $18^{\text {th }} 2014$, we also conducted a CTD-DO survey and collected water samples for $\mathrm{N}_{2} \mathrm{O}$ concentration measurements at an additional inside eddy station (eddy station 2; Fig. 1) on the RV Meteor cruise M105. The CTD-DO sensor was calibrated following the same protocols outlined above, and the standard deviation of duplicate DO measurements by Winkler titration was $\pm 0.35 \mu \mathrm{mol} \mathrm{L}^{-1}$, while the average standard deviation between our discrete Winkler DO measurements and our CTD-DO sensor measurements was $\pm 1.23 \mu \mathrm{mol} \mathrm{L}^{-1}$. To this end, the average propagation of error associated with the DO concentrations we report for eddy station 2 is $\pm 1.28 \mu \mathrm{mol} \mathrm{L}^{-1}$.

$\mathrm{N}_{2} \mathrm{O}$ concentration, and isotope/isotopomer measurements. Water samples for $\mathrm{N}_{2} \mathrm{O}$ concentration, and isotope and isotopomer measurements were collected in duplicate $60 \mathrm{ml}$ and $120 \mathrm{ml}$ serum bottles, respectively, following standard dissolved gas sampling protocols ${ }^{47}$. Immediately following collection, the samples were poisoned with $100 \mu \mathrm{l}$ of a saturated $\mathrm{HgCl}_{2}$ solution and then stored until analysis ashore.

$\mathrm{N}_{2} \mathrm{O}$ concentration samples were stored for $\sim 2$ months prior to being measured on a gas chromatograph with an attached electron capture detector using the headspace equilibration method described by Grundle et al. ${ }^{47}$. Final dissolved $\mathrm{N}_{2} \mathrm{O}$ concentrations were calculated using corresponding measurements of $i n$ situ temperature and salinity, corrected for temperature and pressure during the headspace equilibration following the solubility tables of Weiss and Price ${ }^{48}$. The average standard deviation of our duplicate $\mathrm{N}_{2} \mathrm{O}$ concentration measurements was $\pm 0.8 \mathrm{nmol} \mathrm{L}^{-1}$.

Isotope $\left(\delta^{15} \mathrm{~N}^{\text {bulk }}-\mathrm{N}_{2} \mathrm{O}\right.$ vs. AIR and $\delta^{18} \mathrm{O}-\mathrm{N}_{2} \mathrm{O}$ vs. VSMOW $)$ and isotopomer $\left(\delta^{15} \mathrm{~N}^{\alpha}-\mathrm{N}_{2} \mathrm{O}\right.$ and $\delta^{15} \mathrm{~N}^{\beta}-\mathrm{N}_{2} \mathrm{O}$ vs. AIR) analysis began with continuous helium (He) gas stripping of dissolved $\mathrm{N}_{2} \mathrm{O}$ out of samples as described in Charoenpong et al. ${ }^{49}$. Briefly, sample water was pumped in and out of a gas extractor $\left(14 \mathrm{ml} \mathrm{min}^{-1}\right)$ through which He was constantly bubbled $\left(90 \mathrm{ml} \mathrm{min}^{-1}\right)$. Quantitative yield was verified by comparison of $\mathrm{N}_{2} \mathrm{O}$ recovery from seawater with known $\mathrm{N}_{2} \mathrm{O}$ concentration (established by atmospheric equilibration) and with standard gas injected directly into the He gas flow. Following extraction, the method of McIlvin and Casciotti ${ }^{50}$ was followed in which a purge/trap system was used to purify and concentrate extracted $\mathrm{N}_{2} \mathrm{O}$. This included two-step cryofocusing with passage through $\mathrm{CO}_{2}$ and $\mathrm{H}_{2} \mathrm{O}$ traps as well as a $30 \mathrm{~m} \times 0.53 \mathrm{~mm}$ GS-Q capillary column. Sample $\mathrm{N}_{2} \mathrm{O}$ was introduced via continuous $\mathrm{He}$ carrier flow into a multicollector IsoPrime isotope ratio mass spectrometer (IRMS). Masses 44, 45, and 46, and masses 30 and 31 which arise from the $\mathrm{NO}+$ fragment of $\mathrm{N}_{2} \mathrm{O}$ which is formed in the ion source, were monitored, and sample $\mathrm{N}_{2} \mathrm{O}$ was detected as a well-resolved sharp peak which was bracketed by broader reference $\mathrm{N}_{2} \mathrm{O}$ peaks. The $45 / 44$ and $46 / 44$ peak areas were used to derive $\delta^{18} \mathrm{O}-\mathrm{N}_{2} \mathrm{O}$ and $\delta^{15} \mathrm{~N}^{\text {bulk }}-\mathrm{N}_{2} \mathrm{O}$, respectively, while the $31 / 30$ peak area was used to derive $\delta^{15} \mathrm{~N}^{\alpha}-\mathrm{N}_{2} \mathrm{O}$. The $\delta^{15} \mathrm{~N}^{\text {bulk }}-\mathrm{N}_{2} \mathrm{O}$ and $\delta^{15} \mathrm{~N}^{\alpha}-\mathrm{N}_{2} \mathrm{O}$ values were used to calculate $\delta^{15} \mathrm{~N}^{\beta}-\mathrm{N}_{2} \mathrm{O}$. Calibration of $\delta^{15} \mathrm{~N}^{\alpha}-\mathrm{N}_{2} \mathrm{O}, \delta^{15} \mathrm{~N}^{\beta}-\mathrm{N}_{2} \mathrm{O}$ and $\delta{ }^{18} \mathrm{O}-\mathrm{N}_{2} \mathrm{O}$ was 
accomplished using 4 certified standard gases (supplied by Joachim Mohn) ${ }^{51}$ that ranged widely in these values and encompassed those reported here. Calibration for $\mathrm{N}_{2} \mathrm{O}$ site-specific isotopomer composition also needs to account for instrument specific 'scrambling' in the mass spectrometer ion source between ${ }^{15} \mathrm{~N}^{14} \mathrm{NO}$ and ${ }^{14} \mathrm{~N}^{15} \mathrm{NO}^{50}$. The magnitude is on the order of $10 \%$ and is manifested as changes in the $30 / 44$ ratio from the value expected in the absence of scrambling. In order to account for this, we took advantage of new standard materials that vary widely in isotopomer composition ${ }^{51}$ to perform an empirical curve-fitting calibration. Finally, based on measurements of duplicate samples from each sampling depth, the errors associated with our isotope measurements were $\pm 0.07,0.17,0.36$ and $0.18 \%$ for $\delta^{15} \mathrm{~N}^{\text {bulk }}-\mathrm{N}_{2} \mathrm{O}, \delta^{15} \mathrm{~N}^{\alpha}-\mathrm{N}_{2} \mathrm{O}, \delta^{15} \mathrm{~N}^{\beta}-\mathrm{N}_{2} \mathrm{O}$ and $\delta^{18} \mathrm{O}-\mathrm{N}_{2} \mathrm{O}$, respectively.

Molecular genetic analyses. Water samples $(\sim 2 \mathrm{~L})$ were filtered through $0.2 \mu \mathrm{m}$ polyethersulfone membrane filters, which were immediately stored at $-80^{\circ} \mathrm{C}$ until nucleic acid purification was performed ashore following Löscher et al. ${ }^{38}$. RNA was treated with Dnase to remove any residual DNA, and RNA purity was verified by non-template quantitative-PCRs for amoA (ammonia monooxygenase) and nirs (nitrite reductase) genes. Reverse transcription was performed following Löscher et al. ${ }^{38}$. Quantitative-PCRs of bacterial and archaeal $a m o A$ were performed in technical duplicates with standards obtained from Nitrosococcus oceani NC1 and from an environmental clone for archaeal $a m o A^{38}$, while the same was achieved for nirS using a standard obtained from Paracoccus denitrificans $(\mathrm{Pd} 1222)^{38}$. All reactions were performed in a volume of $12.5 \mu \mathrm{l}$ using a ViiA7 quantitative-PCR system following the protocols and PCR conditions outlined by Löscher et al. ${ }^{38}$ and Lam et al. ${ }^{52}$.

\section{References}

1. IPCC. Climate Change (Cambridge Univ. Press, New York, 2014).

2. Bange, H. W. In Nitrogen in the marine environment $2^{\text {nd }}$ edition (eds Capone, D. G. et al.) Ch. 2 (Academic Press, Burlington, 2008).

3. Ravishankara, A. R., Daniel, J. S. \& Portmann, R. W. Nitrous oxide $\left(\mathrm{N}_{2} \mathrm{O}\right)$ : The dominant ozone-depleting substance emitted in the 21st Century. Science 326, 123-125 (2009).

4. Frame, C. H. \& Casciotti, K. L. Biogeochemical controls and isotopic signatures of nitrous oxide production by a marine ammoniaoxidizing bacterium. Biogeosciences 7, 2695-2709 (2010).

5. Goreau, T. J. et al. Production of $\mathrm{NO}_{2}{ }^{-}$and $\mathrm{N}_{2} \mathrm{O}$ by nitrifying bacteria at reduced concentrations of oxygen. Appl. Environ. Microbiol. 40, 526-532 (1980)

6. Mantoura, R. F. C. et al. Nitrogen biogeochemical cycling in the northwestern Indian Ocean. Deep-Sea Res. II 40, 651-671 (1993).

7. Bange, H. W. et al. A revised nitrogen budget for the Arabian Sea. Global Biogeochem. Cycles 14, 1283-1297 (2000).

8. Nevison, C. D., Weiss, R. F. \& Erickson, D. J. III Global oceanic emissions of nitrous oxide. J. Geophys. Res. 100, 15809-15820 (1995).

9. Suntharalingam, P. \& Sarmiento, J. L. Factors governing the oceanic nitrous oxide distribution: Simulations with an ocean general circulation model. Global Biogeochem. Cycles 14, 429-454 (2000).

10. Suntharalingam, P., Sarmiento, J. L. \& Toggweiler, J. R. Global significance of nitrous-oxide production and transport from oceanic low-oxygen zones: A modelling study. Global Biogeochem. Cycles 14, 1353-1370 (2000).

11. Karstensen, J., Stramma, L. \& Visbeck, M. Oxygen minimum zones in the eastern tropical Atlantic and Pacific Oceans. Prog. Oceanogr. 77, 331-350 (2008).

12. Stramma, L., Visbeck, M., Brandt, P., Tanhua, T. \& Wallace, D. Deoxygenation in the oxygen minimum zone of the eastern tropical North Atlantic. Geophys. Res. Lett. 36, L20607 (2009).

13. Ryabenko, E., Kock, A., Bange, H. W., Altabet, M. A. \& Wallace, D. W. R. Contrasting biogeochemistry of nitrogen in the Atlantic and Pacific Oxygen Minimum Zones. Biogeosciences 9, 203-215 (2012).

14. Walter, S., Bange, H. W., Breitenbach \& Wallace, D. W. R. Nitrous oxide in the North Atlantic Ocean. Biogeosciences Discuss., European Geosciences Union 3, 993-1022 (2006).

15. Karstensen, J. et al. Open ocean dead zone in the tropical North Atlantic Ocean. Biogeosciences 12, 2597-2605 (2015).

16. Schütte, F. et al. Characterization of "dead-zone" eddies in the eastern tropical North Atlantic. Biogeosciences 13, 5865-5881 (2016).

17. Fiedler, B. et al. Oxygen utilization and downward carbon flux in an oxygen-depleted eddy in the eastern tropical North Atlantic. Biogeosciences 13, 5633-5647 (2016).

18. Fischer, G. et al. Bathypelagic particle flux signatures from a suboxic eddy in the oligotrophic tropical North Atlantic: production, sedimentation and preservation. Biogeosciences 13, 3202-3223 (2016).

19. Hauss, H. et al. Dead zone or oasis in the open ocean? Zooplankton distribution and migration in low-oxygen modewater eddies. Biogeosciences 13, 1977-1989 (2016).

20. Karstensen, J. et al. Upwelling and isolation in oxygen-depleted anticyclonic modewater eddies and implications for nitrate cycling. Biogeosciences Discuss, doi:10.5194/bg-2016-34 (2016).

21. Löscher, C. R. et al. Hidden biosphere in an oxygen deficient Atlantic open-ocean eddy: future implications of ocean deoxygenation on primary production in the eastern tropical North Atlantic. Biogeosciences 12, 7467-7482 (2015).

22. Stramma, L., Johnson, G. C., Sprintall, J. \& Mohrholz, V. Expanding oxygen-minimum zones in tropical oceans. Science 320, 655-658 (2008).

23. Rees, A. P., Brown, I. J., Clark, D. R. \& Torres, R. The Lagrangian progression of nitrous oxide within filaments formed in the Mauritanian upwelling. Geophys. Res. Lett. 38, L21606 (2011).

24. Frame, C. H., Deal, E., Nevison, C. D. \& Casciotti, K. L. $\mathrm{N}_{2} \mathrm{O}$ production in the eastern South Atlantic: Analysis of $\mathrm{N}_{2} \mathrm{O}$ stable isotopic and concentration data. Global Biogeochem. Cycles 28, 1262-1278 (2014).

25. Babbin, A. R., Bianchi, D., Jayakumar, A. \& Ward, B. B. Rapid nitrous oxide cycling in the suboxic ocean. Science 348, 1127-1129 (2015).

26. Cohen, Y. \& Gordon, L. I. Nitrous oxide in the oxygen minimum zone of the eastern tropical North Pacific: evidence of its consumption during denitrification and possible mechanisms for its production. Deep-Sea Res. 25, 509-524 (1978).

27. Farias, L. et al. Denitrification and nitrous oxide cycling within the upper oxycline of the eastern tropical South Pacific oxygen minimum zone. Limnol. Oceanogr. 54, 132-144 (2009).

28. Yamagishi, H. et al. Role of nitrification and denitrification on the nitrous oxide cycle in the eastern tropical North Pacific and Gulf of California. J. Geophys. Res. 112, G02015 (2007).

29. Nevison, C., Butler, J. H. \& Elkins, J. W. Global distributions of $\mathrm{N}_{2} \mathrm{O}$ and the $\Delta \mathrm{N}_{2} \mathrm{O}$-AOU yield in the subsurface ocean. Global Biogeochem. Cycles 17, 1119 (2003).

30. Naqvi, S. W. A. et al. Nitrogen isotopic studies in the suboxic Arabian Sea. Journal of Earth System Science 197, 367-378 (1998).

31. Naqvi, S. W. A. et al. Budgetary and biogeochemical implications of $\mathrm{N}_{2} \mathrm{O}$ isotope signatures in the Arabian Sea. Nature 395, 462-494 (1998b).

32. Farias, L., Besoain, V. \& Garcia-Loyola, S. Presence of nitrous oxide hotspots in the coastal upwelling area off central Chile: an analysis of temporal variability based on ten years of biogeochemical time series. Environ. Res. Lett. 10, 044017 (2015).

33. Cohen, Y. Consumption of dissolved nitrous oxide in an anoxic basin, Saanich Inlet, British Columbia. Nature 272, 235-237 (1978).

34. Codispoti, L.A. et al. In Oceanography of the Indian Ocean (ed. Desai, B. N.) 271-284 (Oxford, New Delhi, 1992). 
35. Ji, Q., Babbin, A. R., Jayakumar, A., Oleynik, S. \& Ward, B. B. Nitrous oxide production by nitrification and denitrification in the Eastern Tropical South Pacific oxygen minimum zone. Geophys. Res. Lett. 42, 10755-10764 (2015).

36. Schütte, F., Brandt, P. \& Karstensen, J. Occurrence and characteristics of mesoscale eddies in the tropical northeast Atlantic Ocean. Ocean Sci. Discuss 12, 3043-3097 (2015).

37. Santoro, A.E., Buchwald, C., McIlvin, M.R. \& Casciotti K.L. Isotopic signature of $\mathrm{N}_{2} \mathrm{O}$ produced by marine ammonia oxidizing archaea. Science 333, 1282-1285.

38. Löscher, C. R. et al. Production of oceanic nitrous oxide by ammonia-oxidizing archaea. Biogeosciences 9, 3419-3429 (2012).

39. Sutka, R. L. et al. Distinguishing nitrous oxide production from nitrification and denitrification on the basis of isotopomer abundances. Appl. Environ. Microb. 72, 638-644 (2006).

40. Yung, M.-Y. et al. Isotopic signatures of $\mathrm{N}_{2} \mathrm{O}$ produced by ammonia-oxidizing archaea from soils. ISME J. 8, 115-1125 (2014).

41. Westley, M. B., Yamagishi, H., Popp, B. N. \& Yoshida, N. Nitrous oxide cycling in the Black Sea inferred from stable isotope and isotopomer distributions. Deep-Sea Res. II 53, 1802-1816 (2006).

42. Mothet, A., Sebilo, M., Laverman, A. M., Véronique, V. \& Mariotti, A. Is site preference of $\mathrm{N}_{2} \mathrm{O}$ a tool to identify benthic denitrifier $\mathrm{N}_{2} \mathrm{O}$ ? Environmental Chemistry 10, 281-284 (2013).

43. Popp, B. N. et al. Nitrogen and oxygen isotopomeric constraints in the origins and sea-to-air flux of $\mathrm{N}_{2} \mathrm{O}$ in the oligotrophic subtropical North Pacific gyre. Global Biogeochem. Cycles 16, 1064 (2002).

44. Well, R., Flessa, H., Jaradat, F., Toyoda, S. \& Yoshida, N. Measurement of isotopomer signatures of $\mathrm{N}_{2} \mathrm{O}$ in groundwater. J. Geophys. Res. 10, G02006 (2005).

45. Ostrom, N. E. et al. Isotopologue effects during $\mathrm{N}_{2} \mathrm{O}$ reduction in soils and in pure cultures of denitrifiers. J. Geophys. Res. 112, G02005 (2007).

46. Gaurau, B. et al. Thermal lag correction on Slocum CTD glider data. J. Atmos. Ocean. Tech. 28, 1065-1071 (2011).

47. Grundle, D. S., Maranger, R. \& Juniper, S. K. Upper water column nitrous oxide distributions in the northeast subarctic Pacific Ocean. Atmos.-Ocean 50, 7104-7109 (2012).

48. Weiss, R. F. \& Price, B. A. Nitrous oxide solubility in water and sea-water. Mar. Chem. 8, 347-359 (1980)

49. Charoenpong, C. N., Bristow, L. A. \& Altabet, M. A. A continuous flow isotope ratio mass spectrometry method for high precision determination of dissolved gas ratios and isotopic composition. Limnol, Oceanogr. Methods 12, 323-337 (2014).

50. McIlvin, M. R. \& Casciotti, K. L. Fully automated system for stables isotopic analyses of dissolved nitrous oxide at natural abundance levels. Limnol. Oceanogr. Methods 8, 54-66 (2010).

51. Mohn, J. et al. Interlaboratory assessment of nitrous oxide isotopomer analysis by isotope ratio mass spectrometry and laser spectroscopy: current status and perspectives. Rapid Commun. Mass Spectrom. 28, 1995-2007 (2014).

52. Lam, P. et al. Linking crenarchaeal and bacterial nitrification to anammox in the Black Sea. P. Natl. Acad. Sci. USA 104, 7104-7109 (2007).

\section{Acknowledgements}

We thank the Captain and crew of the RV Islandia for their assistance during our cruise to the suboxic eddy, and the National Institute for the Development of Fisheries, Cape Verde, for logistical support. Likewise, we thank S. Christiansen for field support, and D. Nitschkowski, T. Baustian (GEOMAR) and J. Larkum (UMass Dartmouth) for pre-cruise preparation and laboratory support. We also thank the RV Meteor and M. Visbeck, Chief Scientist of M105, for collecting additional $\mathrm{N}_{2} \mathrm{O}$ and dissolved oxygen samples at ES2. This project was funded by the Cluster of Excellence 80 "The Future Ocean" and the BMBF project SOPRAN (grant \#FKZ 03F0662A).The "Future Ocean" is funded within the framework of the Excellence Initiative by the Deutsche Forschungsgemeinshaft (DFG) on behalf of the German federal and state governments. C.R.L. also received funding from $\mathrm{H} 2020$, NITROX \#704272.

\section{Author Contributions}

D.S.G., B.F. and A.K. designed the shipboard sampling portion of the study, and G.K. and J.K. designed and executed the glider surveys of the suboxic eddy. D.S.G. and B.F. conducted field sampling onboard RV Islandia. D.S.G. and H.W.B. were responsible for $\mathrm{N}_{2} \mathrm{O}$ concentration measurements, while D.S.G. and M.A.A. were responsible for the isotope/isotopomer measurements which were conducted using facilities provided by M.A.A. Sampling and measurements of dissolved oxygen were conducted by B.F. The molecular genetic data was processed by C.R.L, and G.K. and J.K. processed the glider data. D.S.G. wrote the manuscript, and all other authors provided feedback.

\section{Additional Information}

Competing Interests: The authors declare that they have no competing interests.

Publisher's note: Springer Nature remains neutral with regard to jurisdictional claims in published maps and institutional affiliations.

Open Access This article is licensed under a Creative Commons Attribution 4.0 International License, which permits use, sharing, adaptation, distribution and reproduction in any medium or format, as long as you give appropriate credit to the original author(s) and the source, provide a link to the Creative Commons license, and indicate if changes were made. The images or other third party material in this article are included in the article's Creative Commons license, unless indicated otherwise in a credit line to the material. If material is not included in the article's Creative Commons license and your intended use is not permitted by statutory regulation or exceeds the permitted use, you will need to obtain permission directly from the copyright holder. To view a copy of this license, visit http://creativecommons.org/licenses/by/4.0/.

(c) The Author(s) 2017 